\title{
EFFECT OF ONE-BOTTLE ADHESIVE SYSTEMS ON THE FLUORIDE RELEASE OF A RESIN-MODIFIED GLASS IONOMER
}

\author{
EFEITO DOS SISTEMAS ADESIVOS DE FRASCO ÚNICO NA \\ LIBERAÇÃO DE FLÚOR DE UM CIMENTO DE IONÔMERO \\ DE VIDRO MODIFICADO POR RESINA
}

\author{
Linda WANG, DDS, MS \\ PhD student of the Department of Operative Dentistry, Endodontics and Dental Materials of Bauru Dental School, University of Sao Paulo, \\ Bauru, Sao Paulo, Brazil. \\ Marília Afonso Rabelo BUZALAF, DDS, MS, PhD \\ Associate Professor of the Department of Biological Sciences of Bauru Dental School, University of Sao Paulo, Bauru, Sao Paulo, Brazil. \\ Maria Teresa ATTA, DDS, MS, PhD \\ Assistant Professor of the Department of Operative Dentistry, Endodontics and Dental Materials of Bauru Dental School, University of \\ Sao Paulo, Bauru, Sao Paulo, Brazil.
}

\begin{abstract}
$\bar{A}$ dhesive systems associated to resin-modified glass ionomer cements are employed for the achievement of a higher bond strength to dentin. Despite this benefit, other properties should not be damaged. This study aimed at evaluating the short-time fluoride release of a resin-modified glass ionomer cement coated with two one-bottle adhesive systems in a pH cycling system. Four combinations were investigated: G1: Vitremer (V); G2: Vitremer + Primer (VP); G3: Vitremer + Single Bond (VSB) and G4: Vitremer + Prime \& Bond 2.1 (VPB). SB is a fluoride-free and PB is a fluoride-containing system. After preparation of the Vitremer specimens, two coats of the selected adhesive system were carefully applied and light-cured. Specimens were immersed in demineralizing solution for 6 hours followed by immersion in remineralizing solution for 18 hours, totalizing the 15-day cycle. All groups released fluoride in a similar pattern, with a greater release in the beginning and decreasing with time. VP showed the greatest fluoride release, followed by V, with no statistical difference. VSB and VPB released less fluoride compared to V and VP, with statistical difference. Regardless the one-bottle adhesive system, application of coating decreased the fluoride release from the resin-modified glass ionomer cements. This suggests that this combination would reduce the beneficial effect of the restorative material to the walls around the restoration.
\end{abstract}

UNITERMS: Glass ionomer cements; Fluorine; Dentin-bonding agents.

\section{INTRODUCTION}

In the last decades, the population has experienced a caries reduction ${ }^{3,6,7}$. However, restoration failures due to caries recurrence are still a challenge ${ }^{6}$. The glass ionomer cement has been used since its development and has been successfully indicated in many situations as a restorative material, luting cement or liner ${ }^{10,23}$. Bonding to tooth structure, biocompatibility with dental tissues, coefficient of thermal expansion similar to enamel and dentin, antibacterial activity and fluoride release are beneficial features that encouraged its utilization, with the expectation of reduced leakage and a greater longevity of the glass ionomer restorations ${ }^{3}$.

However, some disadvantages such as difficult manipulation, poor esthetics, small mechanical resistance and weak cohesive resistance have limited its use ${ }^{22}$. Resin components were introduced in order to overcome these flaws. This process resulted in a stronger material called resin-modified glass ionomer cement ${ }^{12}$ that presents chemical setting and a light curing step due to the monomers in its composition $^{14,22,24}$. These resin monomers led some investigators to propose an association of the resin-modified glass ionomer cement to adhesive systems ${ }^{17,18,20}$. Some authors observed an increase in bond strength with this association $^{17,18}$. 
However, despite the benefit of bond strength, this combination may possibly influence the fluoride release of the material, which is one of the major factors implicated in caries prevention and reduction of secondary caries progression ${ }^{3,16}$. Fluoride-containing dental materials play an important role in oral cavity, enhancing the remineralization process after acid attacks ${ }^{4,13,16}$. Many studies demonstrated that the resin-modified glass ionomer cement also releases significant amounts of fluoride ${ }^{1,14,22}$. So, this feature should be highlighted. Since adhesive agents containing fluoride were also developed, their association to resin-modified glass ionomer cements would be interesting. A previous study demonstrated that fluoride-containing dentin adhesives can release fluoride at sites of microleakage in a restored cavity, and that the hybrid layer had taken it up ${ }^{5}$. Due to the ability of these new products to release fluoride, this study aimed at investigating the role of adhesive systems with and without fluoride in the amount of fluoride release of a resin-modified glass ionomer cement in a $\mathrm{pH}$ cycling system.

\section{MATERIALAND METHODS}

Materials under investigation are presented in Table 1.

\section{Specimen preparation}

Twenty-four disc-shaped specimens of Vitremer for restoration were manipulated according to the manufacturer's instructions at room temperature $\left(23 \pm 1^{\circ} \mathrm{C}\right.$ and $50+5 \%$ relative humidity). The material was dispensed with a Centrix Syringe in plastic moulds (11mm diameter $\mathrm{x}$ $1.5 \mathrm{~mm}$ height). Then, the material was pressed between two matrix strips and glass slides during the setting time. A visible light unit (Optilight 600, Gnatus Equipamentos MedicoOdontologicos LTDA, Ribeirao Preto, SP, Brazil) yielded polymerization for 40 s each side at $450 \mathrm{~mW} / \mathrm{cm}^{2}$, monitored by a radiometer (Demetron Research Corp., Danbury, CT, USA). Subsequently the specimens were randomly selected and assigned to 4 groups: G1- no coating (V); G2- coated with Vitremer Primer (VP); G3- coated with Single Bond(VSB)

TABLE 1- Materials investigated

\begin{tabular}{|c|c|c|c|c|}
\hline Product & Composition & Manufacturer & Batch number & Classification \\
\hline Vitremer & $\begin{array}{c}\text { P: Fluoro- } \\
\text { aluminosilicate } \\
\text { glass, potassium } \\
\text { persulfate, ascorbic } \\
\text { acid } \\
\text { L: 50\% Polycarboxylic } \\
\text { acid copolymer, 20\% } \\
\text { HEMA, water, 13\% } \\
\text { carboxylic acid } \\
\text { copolymer }\end{array}$ & $\begin{array}{c}\text { 3M Dental Products, } \\
\text { St. Paul, MN, USA } \\
55144\end{array}$ & $\begin{array}{c}20010222 \\
\text { Exp. 12-2002 }\end{array}$ & $\begin{array}{l}\text { Resin modified } \\
\text { glass ionomer }\end{array}$ \\
\hline Primer & $\begin{array}{l}\text { 46\% HEMA, 39\% Ethyl } \\
\text { alcohol, } 15 \% \\
\text { Vitrebond copolymer }\end{array}$ & $\begin{array}{c}\text { 3M Dental Products, } \\
\text { St. Paul, MN, USA } \\
55144\end{array}$ & $\begin{array}{c}20010222 \\
\text { Exp. 12-2002 }\end{array}$ & Dentin conditioner \\
\hline Single Bond & $\begin{array}{l}\text { Water, alcohol, HEMA, } \\
\text { BisGMA, DMA, } \\
\text { photoinitiator, } \\
\text { polyacrylic acid } \\
\text { copolymer, } \\
\text { itaconic acid }\end{array}$ & $\begin{array}{c}\text { 3M Dental Products, } \\
\text { St. Paul, MN, USA } \\
55144\end{array}$ & $\begin{array}{c}20010216 \\
\text { Exp. 02-2004 }\end{array}$ & Adhesive system \\
\hline Prime \& Bond 2.1 & $\begin{array}{c}\text { BisGMA, PENTA-P, } \\
\text { photoinitiator, } \\
\text { cetylamine } \\
\text { hydrofluoride, acetone }\end{array}$ & $\begin{array}{c}\text { Dentsply Caulk, } \\
\text { Milford, DE, 19963, } \\
\text { USA }\end{array}$ & $\begin{array}{c}55468 \\
\text { Exp. 03-2002 }\end{array}$ & Adhesive system \\
\hline
\end{tabular}


and G4- coated with Prime \& Bond 2.1 (VPB). After hardening, Groups 2, 3 and 4 received two coats of primer or adhesive systems. Care was taken to cover all exposed surfaces, especially the lateral ones. Light curing was proceeded. Specimens were suspended by a fluoride free dental floss in immersion solutions to avoid any contact with vial walls.

\section{Experimental test}

Specimens were submitted to a $\mathrm{pH}$-cycling model as suggested by Featherstone, et al. ${ }^{4}$ and modified by Carvalho and Cury ${ }^{1}$. Every 24 hours, the specimens were individually maintained in a polyethylene vial containing $3 \mathrm{~mL}$ of a demineralizing solution ( $\mathrm{Ca} 2.0 \mathrm{mM}, \mathrm{PO}_{4} 2.0 \mathrm{mM}$ and acetate buffer 75mM, pH 4.3, containing $\mathrm{Na} \mathrm{N}_{3} 0.02 \%$ ) for 6 hours, followed by immersion in artificial saliva (Ca $1.5 \mathrm{mM}, \mathrm{PO}_{4} 0.9$ $\mathrm{mM}, \mathrm{KCl} 150 \mathrm{mM}$ and Tris buffer $20 \mathrm{mM}$, pH 7.0, containing $\mathrm{NaN}_{3} 0.02 \%$ ) for 18 hours under agitation. The study was conducted for 15 days.

\section{Fluoride analysis}

Fluoride was analyzed using the ion-specific electrode (Orion Research, Cambridge, MA, USA, model 9609) after sample buffering with TISAB III. A set of standards (containing 0.2, 0,4, 0.8, 1.6 and 3.2 ppm fluoride) was prepared using serial dilutions from a 100ppm NaF stock solution (Orion). The millivoltage potentials were converted to $\mathrm{mg}$ fluoride $/ \mathrm{cm}^{2}$ using a standard curve with a coefficient correlation of $r^{3} 0.999$. The mean reproducibility of the readings, based on the duplicate samples, was $97 \%$.

Data were analyzed by one-way ANOVA to compare the different groups at each time period. Tukey test $(\mathrm{p}<0.05)$ was used to identify individual differences.

\section{RESULTS}

The total fluoride released (mean (SD); unit $\mathrm{mg} / \mathrm{cm}^{2}$ ) during the 15-day period was 167.48 (14.25); 176.34 (12.77); 32.51 (20.16); 26.24 (11.52) for V, VP, VSB and VPB, respectively (Table 2). Groups 1 (V) and 2 (VP) released a greater amount with no statistical differences in all periods ( $>0.05$ ). Groups coated with adhesive systems (G3 and G4) demonstrated a significantly lower release when compared to $\mathrm{G} 1$ and $\mathrm{G} 2(\mathrm{p}<0.05)$, yet there were no statistical differences between them $(\mathrm{p}>0.05)$. Coating with the adhesive system clearly decreased the total amount of fluoride release.

Despite the differences, all groups showed a similar pattern of fluoride release. The greatest amount was verified at the first 24 hours (approximately 30\% of the total fluoride release), followed by an evident decrease. After this period, a constant and continuous release was verified in the following 14 days. A higher amount of fluoride release occurred in the demineralizing solution (Table 3) compared

TABLE 2- Mean and standard deviation of cumulative fluoride release $\left(\mu \mathrm{g} / \mathrm{cm}^{2}\right)$ during the 15 -day period of $\mathrm{pH}$ cycling

\begin{tabular}{clll}
\hline Groups & $\begin{array}{c}\text { Demineralizing } \\
\text { solution }\end{array}$ & $\begin{array}{c}\text { Remineralizing } \\
\text { solution }\end{array}$ & $\begin{array}{c}\text { Total fluoride } \\
\text { release }\left(\mu \mathrm{g} / \mathbf{c m}^{2}\right)\end{array}$ \\
\hline 1 & $118.04^{\mathrm{a}}(8.64)$ & $49.45^{\mathrm{a}}(6.04)$ & $167.49^{\mathrm{a}}(14.25)$ \\
2 & $116.43^{\mathrm{a}}(5.39)$ & $59.91^{\mathrm{a}}(9.07)$ & $176.34^{\mathrm{a}}(12.77)$ \\
3 & $23.77^{\mathrm{b}}(15.48)$ & $8.74^{\mathrm{b}}(4.81)$ & $32.51^{\mathrm{b}}(20.16)$ \\
4 & $18.53^{\mathrm{b}}(9.46)$ & $7.71^{\mathrm{b}}(2.30)$ & $26.24^{\mathrm{b}}(11.52)$ \\
\hline
\end{tabular}

Same letters in each column indicate no statistical differences $(p>0.05)$.

TABLE 3- Mean and standard deviation of fluoride release $\left(\mu \mathrm{g} / \mathrm{cm}^{2}\right)$ in the demineralizing solution during the 15-day period

\begin{tabular}{|c|c|c|c|c|c|c|c|c|c|c|c|c|c|c|c|}
\hline Group/day & 1 & 2 & 3 & 4 & 5 & 6 & 7 & 8 & 9 & 10 & 11 & 12 & 13 & 14 & 15 \\
\hline \multirow[t]{2}{*}{1} & 32.72 & 14.95 & 10.08 & 8.31 & 6.38 & 6.28 & 5.44 & 5.11 & 4.45 & 3.90 & 4.23 & 4.21 & 4.09 & 4.02 & 3.86 \\
\hline & (2.77) & $(1.25)$ & (0.99) & $(0.60)$ & $(0.56)$ & $(0.53)$ & $(0.49)$ & $(0.30)$ & $(0.36)$ & $(0.34)$ & $(0.38)$ & $(0.23)$ & $(0.41)$ & $(0.36)$ & $(0.40)$ \\
\hline \multirow[t]{2}{*}{2} & 30.90 & 13.56 & 9.57 & 8.03 & 6.16 & 6.33 & 5.32 & 4.78 & 4.67 & 4.15 & 4.91 & 4.71 & 4.68 & 4.54 & 4.11 \\
\hline & $(1.43)$ & $(0.72)$ & $(0.66)$ & $(0.53)$ & $(0.47)$ & $(0.26)$ & $(0.31)$ & $(0.30)$ & $(0.13)$ & $(0.36)$ & $(0.24)$ & $(0.24)$ & $(0.14)$ & $(0.21)$ & $(0.26)$ \\
\hline & 8.11 & 2.93 & 1.89 & 1.52 & 1.13 & 1.14 & 0.92 & 0.83 & 1.17 & 0.79 & 0.73 & 0.73 & 0.67 & 0.64 & 0.58 \\
\hline & (6.55) & $(2.15)$ & $(1.42)$ & (1.11) & $(0.83)$ & $(0.86)$ & $(0.68)$ & $(0.63)$ & $(0.60)$ & $(0.59)$ & $(0.52)$ & $(0.53)$ & $(0.49)$ & $(0.48)$ & $(0.45)$ \\
\hline & 7.34 & 2.13 & 1.34 & 1.10 & 0.80 & 0.82 & 0.63 & 0.54 & 0.78 & 0.47 & 0.55 & 0.56 & 0.56 & 0.46 & 0.45 \\
\hline & (4.39) & $(1.20)$ & $(0.84)$ & $(0.73)$ & $(0.59)$ & $(0.59)$ & $(0.47)$ & $(0.44)$ & $(0.52)$ & $(0.46)$ & $(0.41)$ & $(0.43)$ & $(0.43)$ & $(0.36)$ & $(0.32)$ \\
\hline
\end{tabular}


to the remineralizing solution (Table 4) for all study groups, although no significant differences were detected for Groups 3 and 4.

\section{DISCUSSION}

This study was conducted according to the $\mathrm{pH}$-cycling model proposed by Featherstone, et al. ${ }^{4}$ in 1986 and modified by Carvalho and Cury ${ }^{1}$ in 1999 . Despite the frequent use of deionized water ${ }^{1,2,9,11,14}$ and artificial saliva ${ }^{1}$ as storage means, they do not simulate the oral environment. A pH cycling model allows a better establishment of oral conditions, reproducing a high caries challenge situation. ${ }^{1}$

Pereira, et al. ${ }^{17}$; Tanumiharja, et al. ${ }^{18}$ associated the resinmodified glass ionomer cement to different bonding agents in an attempt to promote a superior bond strength. This was successfully obtained for different adhesive brands. These results led this association to be of interest in clinical use. Because of these positive results, the prescription of this technique has been considered.

However, this procedure could have other consequences such as a reduction of fluoride ion diffusion into the tooth structure. The adhesive agents could act as a mechanical barrier, especially the fluoride-free ones. It has been previously demonstrated that coating ionomer specimens with some adhesive systems in order to promote surface protection reduced fluoride release ${ }^{2}$.

In our investigation it was evident that the demineralizing solution promoted a higher fluoride release, probably due to its formulation and low $\mathrm{pH}$, when compared to the remineralizing solution ${ }^{1,9,10}$.

In the present study, the fluoride release of Vitremer with no coating is in accordance with other investigations ${ }^{1}$. An initial burst release was detected, followed by a slow release. This is assigned to an acidic-base reaction that occurs in the initial 24-hour period, when fluoride ion dissociation occurs.

Coating Vitremer with its primer increased the fluoride release. A possible explanation may be its more acidic $\mathrm{pH}$. The reduced viscosity of this primer may also contribute to a satisfactory release, yet no statistical difference was observed in relation to the control group. However, a significant difference was observed when the adhesive system was applied, indicating that the properties of the adhesive agent may interfere, probably acting as a mechanical barrier ${ }^{1,21}$. Even though a reduction in the fluoride release was noticed, it was not totally eliminated, which suggests a permeability of this barrier. Some studies showed that single-step, self-etching adhesives behave as permeable membranes after polymerization ${ }^{19}$. As shown by Vercruysse, et al. ${ }^{21}$, although Prime \& Bond 2.1 has fluoride in its composition, this appears to be of little significance, since the fluoride release was smaller when compared to coating with Single Bond. This may be explained by the influence of other factors such as viscosity ${ }^{2}$, thickness ${ }^{19}, \mathrm{pH}^{15}$ and homogeneity of the bonding agent application ${ }^{2}$. Differences in the permeability of adhesive systems depend on their formulations ${ }^{21}$. Although Prime \& Bond 2.1 was less effective as a fluoride source, other studies demonstrated that a fluoride containing adhesive agent is effective in situations when microleakage is occurring ${ }^{5}$. This causes the formation of a caries inhibition zone, which may be attributed to the presence of fluoride, in association to other ions like calcium and phosphate.

More studies are needed to confirm these findings. Regardless many investigation efforts, the fluoride therapeutic amounts are not yet established ${ }^{8}$.

Thus, despite the ability of fluoride release, the interaction of the restorative material with the adhesive system of choice is of great importance, associated to other relevant properties like bond strength and adhesion to the tooth structure.

Clinical studies should be conducted to confirm the benefit of the association of resin-modified glass ionomer cement and adhesive systems. So far this procedure may not be considered superior, although many studies have presented satisfactory bond strength to dental hard tissues. Evidences of fluoride release reduction call for further investigation prior to the indication of this association in clinical routine.

TABLE 4- Mean and standard deviation of fluoride release $\left(\mu \mathrm{g} / \mathrm{cm}^{2}\right)$ in the remineralizing solution during the 15-day period

\begin{tabular}{|c|c|c|c|c|c|c|c|c|c|c|c|c|c|c|c|}
\hline Group/day & 1 & 2 & 3 & 4 & 5 & 6 & 7 & 8 & 9 & 10 & 11 & 12 & 13 & 14 & 15 \\
\hline \multirow[t]{2}{*}{1} & 13.33 & 6.07 & 3.94 & 2.63 & 2.96 & 2.89 & 2.47 & 2.40 & 2.31 & 2.05 & 2.02 & 1.98 & 1.91 & 1.69 & 0.81 \\
\hline & (1.72) & (0.95) & $(0.60)$ & $(0.43)$ & $(0.38)$ & $(0.49)$ & $(0.23)$ & $(0.67)$ & $(0.26)$ & $(0.20)$ & (0.19) & $(0.27)$ & $(0.23)$ & $(0.16)$ & $(0.08)$ \\
\hline \multirow[t]{2}{*}{2} & 17.22 & 7.59 & 5.20 & 3.34 & 2.81 & 3.51 & 2.86 & 2.67 & 2.70 & 2.39 & 2.30 & 2.22 & 2.23 & 1.80 & 1.08 \\
\hline & $(2.82)$ & $(1.42)$ & $(1.12)$ & $(0.62)$ & $(0.51)$ & $(0.49)$ & $(0.40)$ & $(0.35)$ & $(0.25)$ & $(0.26)$ & $(0.23)$ & $(0.20)$ & $(0.43)$ & $(0.11)$ & $(0.35)$ \\
\hline \multirow[t]{2}{*}{ 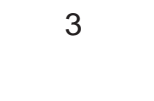 } & 1.74 & 0.92 & 0.65 & 0.57 & 0.50 & 0.52 & 0.47 & 0.45 & 0.49 & 0.46 & 0.44 & 0.41 & 0.39 & 0.36 & 0.35 \\
\hline & (1.44) & $(0.71)$ & $(0.44)$ & $(0.42)$ & $(0.37)$ & $(0.35)$ & $(0.32)$ & $(0.32)$ & $(0.31)$ & $(0.28)$ & $(0.27)$ & $(0.27)$ & $(0.26)$ & $(0.24)$ & $(0.24)$ \\
\hline \multirow[t]{2}{*}{4} & 1.60 & 0.81 & 0.60 & 0.53 & 0.48 & 0.49 & 0.42 & 0.40 & 0.41 & 0.37 & 0.36 & 0.34 & 0.32 & 0.29 & 0.27 \\
\hline & (0.81) & $(0.38)$ & $(0.30)$ & (0.29) & $(0.25)$ & $(0.26)$ & $(0.23)$ & $(0.21)$ & $(0.26)$ & $(0.24)$ & $(0.22)$ & $(0.23)$ & $(0.23)$ & $(0.21)$ & (0.19) \\
\hline
\end{tabular}




\section{ACKNOWLEDGEMENTS}

The authors wish to acknowledge Dr. Ricardo Marins de Carvalho for his suggestions; Dr. José Roberto Pereira Lauris for the statistical analysis and Thelma Lopes da Silva for the laboratory technical support. CAPES partially supported this work.

\section{RESUMO}

Sistemas adesivos são associados aos cimentos de ionômero de vidro modificados por resina para a obtenção de maior resistência adesiva à dentina. Apesar deste benefício, outras propriedades não devem ser prejudicadas. Este estudo se propôs a avaliar a liberação de flúor a curto prazo de um cimento de ionômero de vidro modificado por resina coberto com dois diferentes sistemas adesivos em um modelo de ciclagem de $\mathrm{pH}$. Quatro associações foram testadas: G1: Vitremer (V); G2: Vitremer + Primer (VP); G3: Vitremer + Single Bond (VSB) and G4: Vitremer + Prime \& Bond 2.1 (VPB). SB é um sistema sem flúor e PB contém flúor. Após a confecção das amostras de Vitremer, duas camadas de cada sistema selecionado foram aplicadas e fotopolimerizadas. Em seguida, as amostras foram imersas em solução desmineralizante por 6 horas, seguida da imersão em solução remineralizante por 18 horas, totalizando 15 dias de ciclagem. Todos os grupos liberaram flúor sob o mesmo padrão, apresentando maior liberação inicial e decrescendo ao longo do tempo. VP apresentou a maior liberação de flúor, seguida de V, sem diferença estatística. VSB and VPB liberaram menor quantidade de flúor em relação a V e VP, com diferenças estatisticamente significantes. Independentemente do sistema adesivo de frasco único, houve redução da liberação de flúor pelo cimento de ionômero de vidro modificado por resina. Isto sugere que esta associação poderia reduzir o efeito benéfico do material restaurador em torno da restauração.

UNITERMOS: Cimentos de ionômero de vidro; Flúor; Adesivos dentinários.

\section{REFERENCES}

1- Carvalho AS, Cury JA. Fluoride release from some dental materials in different solutions. Oper Dent 1999; 24:14-9.

2- Castro GW, Gray SE, Buikema DJ, Reagan SE. The effect of various surface coatings on fluoride release from glass-ionomer cement. Oper Dent 1994; 19: 194-8.

3- Donly KJ. Enamel and dentin demineralization inhibition of fluoride-releasing materials. Am J Dent 1994; 7: 275-8.

4- Featherstone JDB, O’Reilly MM, Shariati M, Brugler S. Enhancement of remineralization in vitro and in vivo in factors relating to demineralization and remineralization of the teeth Oxford: IRL Press 1986; 23-34.
5- Ferracane JL, Mitchem JC, Adey JD. Fluoride penetration into the hybrid layer from a dentin adhesive. Am J Dent 1998; 11:238

6- Forsten L. Fluoride release and uptake by glass-ionomers and related materials and its clinical effect. Biomaterials 1998; 19:5038.

7- Friedl K-H, Schmalz G, Hiller K-A, Shams M. Resin-modified glass ionomer cements: fluoride release and influence on streptococcus mutans growth. Eur J Oral Sci 1997; 105:81-5.

8- Hellwig E, Lussi A. What is the optimum fluoride concentration needed for the remineralization process? Caries Res 2001; 35 (suppl. 1): 57-9.

9- Karantakis P, Helvatjoglou-Antoniades M, Theodoridou-Pahini S, Papadogiannis Y. Fluoride release from three glass ionomers, a compomer, and a composite resin in water, artificial saliva, and lactic acid. Oper Dent 2000; 25: 20-5.

10- Marks LAM, Verbeeck RMH, De Maeyer EAP, Martens LC. Effect of a neutral citrate solution on the fluoride release of resinmodified glass ionomer and polacid-modified composite resin cements. Biomaterials 2000; 21: 2011-6.

11- Mazzaoui SA, Burrow MF, Tyas MJ. Fluoride release from glass ionomer cements and resin composites coated with a dentin adhesive. Dent Mater 2000; 16: 166-71.

12- Mc Lean JW, Nicholson JW, Wilson AD. Proposed nomenclature for glass-ionomer dental cements and related materials. Quintessence Int 1984; 25:587-9.

13- McKnight-Hanes, Whitford GM. Fluoride release from three glass ionomer materials and the effects of varnishing with or without finishing. Caries Res 1992; 26: 345-50.

14- Momoi Y, McCabe JF. Fluoride release from light-activated glass ionomer restorative cements. Dent Mater 1993; 9:151-4.

15- Nicholson JW, Millar BJ, Czarnecka B, Limanowska-Shaw H. Storage of polyacid-modified resin composites (“compomers”) in lactic acid solution. Dent Mater 1999; 15 :413-6.

16- Pereira PNP, Inokoshi S, Tagami J. In vitro secondary caries inhibition around fluoride releasing materials. J Dent 1998; 26:50510.

17- Pereira PNP, Yamada T, Inokoshi S, Burrow MF, Sano H, Tagami J. Adhesion of resin-modified glass ionomer cements using resin bonding systems. J Dent 1998; 26: 479-85.

18- Tanumiharja M, Burrow MF, Tyas MJ. Microtensile bond strengths of glass ionomer (polyalkenoate) cements to dentine using four conditioners. J Dent 2001; 28: 361-6.

19- Tay FR, Pashley DH, Suh BI, Carvalho RM, Itthagarum. Single-step adhesives behave are permeable membranes. J Dent 2002; 30: 371-82.

20- Vargas MA, Fortin D, Swift EJ. Bond strengths of glass ionomers using a dentin adhesive. Am J Dent 1995; 8: 197-200. 
21- Vercruysse CWJ, De Maeyer EAP, Verbeeck RMH. Fluoride release of polyacid-modified composite resins with and without bonding agents. Dent Mater 2001; 17:354-8.

22- Vermeersch G, Leloup G, Vreven J. Fluoride release from glass -ionomer cements, compomers and resin composites. J Oral Rehabil 2001; 28: 26-32.

23- Wilson AD, Kent BE. The glass-ionomer cement: a new translucent dental filling material. J Appl Chem Biotechnol 1971; 21:313.

24- Yoshioka M, Yoshida Y, Inoue S, Lambrechts P, Vanherle G, Nomura Y, Okazi M, Shintani H, Van Meerbeek B. Adhesion/ decalcification mechanisms of acid interactions with human hard tissues. J Biomed Mater Res 2002; 59: 56-62.

Recebido para publicação: 24/04/2003

Enviado para reformulações: 06/06/2003

Pronto para publicação: 05/08/2003

\section{Correspondence:}

Maria Teresa Atta

Alameda Octávio Pinheiro Brisolla, 9-75

CEP 17012-901 Bauru, SP, Brazil

Phone : 5514 235-8358

FAX:55 14 223-4679

E-mail:teresatta@bol.com.br 